\title{
The Impact of Traditional Silvopastoral System on the Mixed Ombrophilous Forest Remnants
}

\author{
Lígia Carolina Alcântara Pinotti ${ }^{1}$, Ana Lúcia Hanisch², \\ Raquel Rejane Bonato Negrelle ${ }^{1}$ \\ ${ }^{1}$ Setor de Ciências Agrárias, Universidade Federal do Paraná - UFPR, Curitiba/PR, Brasil \\ ${ }^{2}$ Empresa de Pesquisa Agropecuária e Extensão Rural - EPAGRI, Canoinhas/SC, Brasil
}

\begin{abstract}
The results of an evaluation of the impact of traditional silvopastoral system on floristic and phytosociology of the Mixed Ombrophilous Forest (MOF) remnants, named caívas, in the North Plateau of Santa Catarina, South of Brazil are shown here to contribute to a better understanding of the impact of human activities on natural environments,. There was significant heterogeneity in floristic and structural aspects among the remnants. They exhibited high floristic integrity, with the presence of species typically registered in MOF. On the other hand, the incidence of exotic species was inexpressive. The predominance of smaller plant individuals than expected for adults of the species, combined with the predominance of secondary and pioneer species indicate the occurrence of repeated disturbances over the years. It is urgent to identify technological alternatives to enable appropriate foraging and increase in livestock production, ensuring economic and social sustainability with less environmental impact.
\end{abstract}

Keywords: Araucaria Forest, biodiversity, environmental conservation. 


\section{INTRODUCTION}

A phytoecological unit of the Atlantic Forest biome called Mixed Ombrophilous Forest (MOF), or Araucaria Forest has this name due to the occurrence of Araucaria angustifolia (Bertol.) Kuntze as symbol-species of its composition (Vibrans et al., 2011). In addition to this type of tree, MOF is characterized by species of tropical and temperate flora, with four sub-formations identified by their features and floristic composition, which vary according to the environment altitudes: Alluvial, Submontana ( $\leq 400$ meters above sea level), Montana ( $>400$ and $\leq 1.000$ meters above sea level), and Altomontana ( $\geq 1.000$ meters above sea level) (Klauberg et al., 2010).

Before the $19^{\text {th }}$ century Brazilian colonization and territorial occupation, MOF growth within its original $200.000 \mathrm{~km}$ of mountains and plateaus intercalated with native fields have been uninterrupted (Lacerda, 2016). Currently, MOF is highly fragmented with less than $1 \%$ of its original area, with few representative remnants that preserve biodiversity, as result of the history of anthropogenic processes, such as intense exploitation of timber with high economic value (Marques et al., 2012; Vibrans et al., 2013; Lacerda, 2016).

In the North Plateau of Santa Catarina, MOF is composed of cultivation areas and grazing areas, merged with forest fragments. These areas have existed for more than 50 years as a traditional silvopastoral system named caíva (Hanisch et al., 2010; Mello \& Peroni, 2015). They are heterogeneous and have variations in the densities of the arboreal, shrub and herbal strata. There are areas with predominance of yerba mate (Ilex paraguariensis A. St.-Hil.) and tree component classified in the advanced succession stage (Reis et al., 2013). The synergism in these environments is among the components of the system as common denominator, allowing several productive arrangements (Bonn et al., 2011).

Thus, caívas represent areas that have important properties. They are a space for raising and feeding dairy cattle, and they are also used for the production of native yerba mate and pinion collection (Mello \& Peroni, 2015). Therefore, they have great socioeconomic importance, as well as relevance for biodiversity conservation of the remnants of MOF in that region (Marques et al., 2012).
However, the environmental impact of the anthropogenic use of these remnants in this model is still poorly understood. Given that this process historically continues to exist without the elimination of the remaining forest, a certain advantage and strategy for success of the biodiversity maintenance and conservation of that ecosystem are assumed (Hanisch et al., 2010). Additionally, Souza et al. (2012) found that disturbances and impacts caused by logging and multiple uses in areas of MOF had a certain resilience in angiosperm tree species. Nonetheless, the areas presented reduction in species richness, lack of tree regeneration and reduction in the density of the tree fragments analyzed that had chronically been disturbed.

Understanding the processes that shape communities under the anthropic disturbance, how they occur as a result of the forest successional stage, and the use of the forest remnants will provide more accurate information for better targeting conservationist practices (Zamorano-Elgueta et al., 2014).

In order to contribute to a better understanding of the impact of human activities on natural environments, this study shows the results of the impact evaluation of traditional silvopastoral system, regionally named caíva, on the floristic composition and phytosociological structure in the remnants of MOF, in the North Plateau of Santa Catarina, South of Brazil. Based on the results, there is a discussion on the implications of the silvopastoral management within the remnants of MOF outside conservation units, a proper maintenance of these environments is recommended.

\section{MATERIALS AND METHODS}

The study was conducted in seven remnant areas of MOF undergoing traditional silvopastoral system, regionally called caívas, located in rural properties in the North Plateau of Santa Catarina, South of Brazil. Remnant areas of at least 1 ha, with no history of clear-cutting, but with history of more than 50 years of selective cutting of tree species for domestic use of wood were selected.

These properties had crops and dairy cattle, with the caivas used as setting for raising and grazing the animals, and for extracting native yerba mate. In three of the properties, the caívas have undergone traditional management, with spontaneous native pasture without 
oversowing. In other three properties, the caivas had annual grass and winter legume oversowing (among these: Lolium multiflorum L. - ryegrass, Avena strigosa Schreb. - black oat, Vicia sativa L. - common vetch, and Trifolium repens L. - white clover) for about 3 years. In only one caíva, a sort of summer perennial grass (Axonopus catharinensis Valls - giant missionary grass) had been planted by division of clumps. All areas were subjected to periodic mowing, mainly to facilitate the collection of yerba mate, which occurred every two years (Table 1).

According to the classification of Köppen-Geiger, the climate is $\mathrm{Cfb}$, with average temperatures below $18^{\circ} \mathrm{C}$ in the coldest month, with frequent frost, and average temperatures below $22^{\circ} \mathrm{C}$ in the warmest month, with cool summers. It features indefinite dry season, with well-distributed rain along the months (Gasper et al., 2013). The area is characterized by gently rolling relief and encompasses predominantly the soil type Dystrophic Red Latosol (Typic Haplorthox), with the original vegetation categorized as MOF Montana (Hanisch et al., 2010).

Samples of fertile and vegetative plant material were systematically collected in the chosen areas and in their herborized surroundings, as stated Fidalgo \& Bononi (1989). Then, the botanical material was placed in the Herbarium "Escola de Florestas de Curitiba" - EFC, in the reference collection at EPAGRI in Canoinhas-SC and in the Laboratory OIKOS of the Federal University of Paraná (UFPR), in Curitiba-PR.

A central area of 0.5 hectares was selected in the remnants In each sample unit and subdivided into 50 contiguous plots of $10 \times 10$ meters. Within each of these plots, all arboreal individuals $(\mathrm{DBH} \geq 5.0 \mathrm{~cm}$, height $>1.30 \mathrm{~m}$ ) and palm trees were identified, measured and mapped using the coordinate system. These records were used to quantify the following structural descriptors: frequency, density, dominance, importance value and basal area (sensu Mueller-Dombois \& Ellenberg, 1974).

The usual categories presented in the IBGE (2012) were used for the evaluation of the vertical stratification, defined by height classes: macro-phanerophyte $(\geq 30 \mathrm{~m})$, meso-phanerophyte $(\geq 20<30 \mathrm{~m})$, micro-phanerophyte $(\geq 5<20 \mathrm{~m})$ and nano-phanerophyte $(>0.25<5 \mathrm{~m})$. For this purpose, the maximum expected height for the species when adult was considered, obtained from a literature review (potential height).

Data on the phytogeographical domains of the species were obtained in Flora do Brasil (2016). The information relating to the successional status of these species was obtained from Meyer et al. (2013).

The evaluation of the floristic similarity in the areas was performed using the binary Sørensen Index $\left(\mathrm{IS}_{\varnothing}\right)$. The diversity was estimated by Shannon Index $\left(\mathrm{H}^{\prime}\right)$ and the distribution of the abundance by the Pielou

Table 1. Summary of the managements performed in the caívas, where the floristic and structural aspects of the arboreal component were collected (Santa Catarina, 2015).

\begin{tabular}{|c|c|c|c|c|c|c|c|}
\hline Caíva & Municipality & $\begin{array}{l}\text { Latitude / } \\
\text { Longitude }\end{array}$ & Altitude & Mowing & $\begin{array}{c}\text { Pasture } \\
\text { (herbaceous cover) }\end{array}$ & $\begin{array}{l}\text { Animal } \\
\text { Capacity } \\
\left(\text { UA.ha }^{-1}\right)\end{array}$ & $\begin{array}{c}\text { Density } \\
\text { Yerba Mate }^{\star} \\
\text { (ind.ha- }^{-1} \text { ) }\end{array}$ \\
\hline $\mathrm{C} 1$ & Canoinhas & $\begin{array}{l}26^{\circ} 13^{\prime} 25^{\prime \prime} \mathrm{S} \\
50^{\circ} 22^{\prime} 07^{\prime \prime} \mathrm{W}\end{array}$ & $805 \mathrm{~m}$ & Annual & Oversowing & 2.0 & High \\
\hline $\mathrm{C} 2$ & Canoinhas & $\begin{array}{l}26^{\circ} 13^{\prime} 24^{\prime \prime} \mathrm{S} \\
50^{\circ} 22^{\prime} 12^{\prime \prime} \mathrm{W}\end{array}$ & $808 \mathrm{~m}$ & Annual & $\begin{array}{l}\text { Perennial grass } \\
\text { planted }\end{array}$ & 2.0 & Mean \\
\hline C3 & Canoinhas & $\begin{array}{l}26^{\circ} 09^{\prime} 36^{\prime \prime} \mathrm{S} \\
50^{\circ} 27^{\prime} 42^{\prime \prime} \mathrm{W}\end{array}$ & $810 \mathrm{~m}$ & Annual & Spontaneous native & 0.35 & Low \\
\hline $\mathrm{C} 4$ & Irineópolis & $\begin{array}{l}26^{\circ} 18^{\prime} 26^{\prime \prime} \mathrm{S} \\
50^{\circ} 51^{\prime} 22^{\prime \prime} \mathrm{W}\end{array}$ & $773 \mathrm{~m}$ & Quarterly & Spontaneous native & 0.35 & High \\
\hline C5 & Irineópolis & $\begin{array}{l}26^{\circ} 18^{\prime} 34^{\prime \prime} \mathrm{S} \\
50^{\circ} 51^{\prime} 26^{\prime \prime} \mathrm{W}\end{array}$ & $788 \mathrm{~m}$ & Quarterly & Oversowing & 2.0 & Mean \\
\hline C6 & Irineópolis & $\begin{array}{l}26^{\circ} 18^{\prime} 28^{\prime \prime} \mathrm{S} \\
50^{\circ} 51^{\prime} 54^{\prime \prime} \mathrm{W}\end{array}$ & $775 \mathrm{~m}$ & Annual & Spontaneous native & 0.35 & High \\
\hline $\mathrm{C} 7$ & Três Barras & $\begin{array}{l}26^{\circ} 09^{\prime} 52^{\prime \prime} \mathrm{S} \\
50^{\circ} 19^{\prime} 24^{\prime \prime} \mathrm{W}\end{array}$ & $814 \mathrm{~m}$ & Annual & Oversowing & 2.0 & Low \\
\hline
\end{tabular}

* density categories established from the maximum and minimum numbers of yerba mate plants registered in the floristic survey conducted in the caivas studied, namely: high $\geq 280$ plants.ha $^{-1}$; mean $=161$ to 280 plants.ha $^{-1}$; low $\leq 161$ plants.ha ${ }^{-1}$. 
evenness Index (J') (Mueller-Dombois \& Ellenberg, 1974). The difference regarding the diversities obtained in the evaluated caívas was verified by the Hutcheson $t$-test, $\mathrm{p}<0.05$ (Magurran, 1988).

The results of the seven caívas survey were contrasted with those relating to the MOF under the same conditions of altitude reported in the Floristic and Forest Inventory of Santa Catarina (Vibrans et al., 2013), as well as with surveying data on areas of caívas reported in Hanisch et al. (2010) and surveying data on MOF preservation units reported in Klauberg et al. (2010). For this analysis, the results were extrapolated to make the sample area compatible, and/or to adjust the inclusion criterion to $\mathrm{DBH} \geq 10$ centimeters, when necessary. The difference between the averages presented by the papers was tested by the Student's $t$-test $(\mathrm{p}<0.05)$.

\section{RESULTS}

In floristic terms, a total of 59 arboreal species belonging to 44 genera and 30 families were identified. From this total of species, $72.4 \%$ are of wider distribution in the Brazilian biome, $33 \%$ of all occurrences are registered within the Atlantic Forest phytogeographic domain and only one is naturalized exotic species (Citrus reticulata). Only three species of recorded occurrence in the Atlantic Forest were regarded as reportedly occurring only in the MOF: Curitiba prismatica, Mimosa scabrella and Picramnia excelsa (Appendix A).

In average, a value of $H^{\prime}=1.75 \pm 0.55$ for the Shannon's diversity index was registered, and most of the diversity indices of the sample units are significantly different from each other. The observed mean richness was of $25.14 \pm 5.81$ arboreal species and $15.57 \pm 3.05$ families per hectare, with a predominance of a high floristic dissimilarity among the evaluated areas (Tables 2 to 4 ).

A relatively similar abundance distribution pattern was observed in the existing species of the evaluated caívas, registering low to moderate evenness $\left(\mathrm{J}_{\text {mean }}^{\prime}=0.55 \pm 0.16, \mathrm{~J}_{\min }^{\prime}=0.36 ; \mathrm{J}_{\text {max }}^{\prime}=0.75\right)$. Regarding the structural parameters, density averages of $243 \pm 60.34$ of arboreal individuals per hectare, mean basal area of $11.57 \pm 1.15 \mathrm{~m}^{2} . \mathrm{ha}^{-1}$ and canopy height of $21.47 \pm 4.58 \mathrm{~m}$ were registered.

Ilex paraguariensis was pointed out as the species with highest importance value on six of the seven assessed areas due to its high rates of relative density, relative frequency and relative dominance (C1, C2, C4, C5, C6 and C7). Along with this species, others were also registered with elevated importance values: Araucaria angustifolia (4 caívas), Ocotea porosa ( 4 caívas); Cupania vernalis ( 3 caívas), Casearia obliqua (2 caívas) and Curitiba prismatica (2 caívas).

All caívas had similar vertical stratification patterns, while the occurrence of distinct layers was detected, with emerging individuals (height $\geq 20 \mathrm{~m}$, $\max =30 \mathrm{~m}$ ), individuals composing the canopy (height $\geq 10$ and $<20 \mathrm{~m}$ ) and the sub-canopy (height $<10 \mathrm{~m}$ ). There were 19 species identified as emergent, of which Araucaria angustifolia and Ocotea porosa were the most

Table 2. Floristic characteristics evidenced in the caívas (Santa Catarina, 2015).

\begin{tabular}{cccccc} 
Local & AD & S & H' & var $\left(H^{\prime}\right)$ & J' \\
\hline C1 & 580.00 & 23 & 1.59 & 0.0087 & 0.51 \\
C2 & 478.72 & 30 & 1.79 & 0.0086 & 0.53 \\
C3 & 519.15 & 35 & 2.65 & 0.0069 & 0.75 \\
C4 & 665.31 & 25 & 1.14 & 0.0082 & 0.36 \\
C5 & 470.00 & 25 & 1.87 & 0.0107 & 0.58 \\
C6 & 541.30 & 20 & 1.09 & 0.0102 & 0.36 \\
C7 & 293.33 & 18 & 2.13 & 0.0074 & 0.74 \\
\hline
\end{tabular}

$\mathrm{AD}=$ absolute density $\left(\right.$ ni.ha $\left.^{-1}\right) ; \mathrm{S}=$ specific richness (number of species); H' = Shannon's diversity index; var = variance; $\mathrm{J}^{\prime}=$ Pielou's evenness index.

Table 3. Matrix of results of the Hutcheson $t$-test for the diversity H' among caívas (Santa Catarina, 2015).

\begin{tabular}{cccccccc} 
Caíva & C1 & C2 & C3 & C4 & C5 & C6 & C7 \\
\hline C1 & -- & & & & & & \\
\hline C2 & -1.53 & -- & & & & & \\
\hline C3 & -8.53 & -6.95 & -- & & & & \\
C4 & $3.43^{\star}$ & $4.98^{*}$ & $12.27^{\star}$ & -- & & & \\
\hline C5 & -1.99 & -0.55 & $5.95^{*}$ & -5.25 & -- & & \\
\hline C6 & $3.64^{*}$ & $5.12^{*}$ & $11.98^{*}$ & 0.41 & $5.38^{*}$ & -- & \\
\hline C7 & -4.28 & -2.71 & $4.36^{*}$ & -7.89 & -1.98 & -7.86 & -- \\
\hline
\end{tabular}

*Indicates significant difference among caívas; degrees of freedom $=\infty$; significance level $=0.05 ; \mathrm{t}_{\text {tab }}$ value $=1.96$.

Table 4. Similarity measure of IS $_{\varnothing}$ among caívas (Santa Catarina, 2015).

\begin{tabular}{cccccccc} 
Caíva & C1 & C2 & C3 & C4 & C5 & C6 & C7 \\
\hline C1 & 1.00 & & & & & & \\
C2 & 0.64 & 1.00 & & & & & \\
\hline C3 & 0.48 & 0.65 & 1.00 & & & & \\
C4 & 0.38 & 0.51 & 0.50 & 1.00 & & & \\
\hline C5 & 0.50 & 0.58 & 0.50 & 0.64 & 1.00 & & \\
C6 & 0.42 & 0.52 & 0.44 & 0.58 & 0.67 & 1.00 & \\
\hline C7 & 0.49 & 0.46 & 0.53 & 0.47 & 0.47 & 0.32 & 1.00 \\
\hline
\end{tabular}


representative in quantity of individuals. The canopy had the highest diversity, comprising 45 species, of which Ocotea porosa and Ocotea puberula are the most representative in quantity of individuals. The sub-canopy had intermediary diversity figures with 39 species, of which the Ilex paraguariensis, Curitiba prismatica, and Annona rugulosa species presented the highest quantity of individuals in this stratum.

A consistent representation pattern of the categories of the arboreal habit among the evaluated caívas was also detected, with most of the sampled species (82.42\%) comprising micro-phanerophytes, and with low representation of meso-phanerophyte (11.64\%) and macro-phanerophyte (5.88\%). The occurrence of a nano-phanerophyte species $(0.06 \%)$ was recorded in only one of the caívas (Appendix A). Ilex paraguariensis was the micro-phanerophyte species with the highest density in all of the evaluated caívas, often accompanied by Casearia obliqua and Annona rugulosa. Representatives of the Lauraceae stood out among the meso-phanerophyte, especially the Ocotea porosa. The group of the macro-phanerophyte was essentially represented by the Araucaria angustifolia at low densities, along with the Cedrela fissilis in two of the caívas.

In most of the evaluated areas there was a predominance of secondary species, with relative lower representation of pioneer species and low occurrence of climatic species (Appendix A). In terms of absolute density, $73.6 \%$ of the total of the individuals were included in the pioneer category, $21.1 \%$ were secondary and $0.88 \%$ were climatic individuals, as well as $4.5 \%$ with undefined successional status.

Compared to the results presented for the MOF, under the same conditions of altitude and inclusion criteria reported in the Floristic and Forest Inventory of Santa Catarina (Meyer et al., 2013), similar rates of mean absolute density per hectare were observed, with no statistical difference. However, the studied caívas had significantly different and lower mean values for specific richness, diversity $\left(\mathrm{H}^{\prime}\right)$ and evenness ( $\left.\mathrm{J}^{\prime}\right)$, as well as reduced mean basal area. The comparative analysis also revealed floristic dissimilarity between the species with the highest importance values registered in the caívas and those reported for the MOF in Meyer et al. (2013) (Table 5).

Regarding the surveyed data in areas of caívas reported in Hanisch et al. (2010), there were similar values of richness, density, and basal area, despite the dissimilarity in the species of higher IV. The values for diversity $\mathrm{H}^{\prime}$ and evenness J' were significantly different and lower than those values observed in Hanisch et al. (2010) (Table 5).

When comparing the data surveyed in MOF conservation units reported in Klauberg et al. (2010), lower values for specific richness, basal area, diversity $\mathrm{H}$ ' and evenness J' were observed, as well as a significant difference in the mean absolute density, which was lower in caívas against UC. In this comparison, dissimilarities among the species of highest IV also became evident (Table 5).

\section{DISCUSSION}

Despite the display of inherent heterogeneity to the remaining MOF, as extensively reported in the literature (Amaral et al., 2013; Meyer et al., 2013), it was possible to verify that the studied caívas presented high flora integrity. Thus, in the species recorded, there were those normally registered for MOF, practically without the presence of exotic species that are often part of the landscape in the area of occurrence of MOF (Vibrans et al., 2013). In the composition of MOF communities, in addition to Araucaria, Lauraceae species are expected to appear (e.g. Ocotea porosa, Ocotea pulchella, Ocotea puberula, Nectandra lanceolata, Nectandra megapotamica), as well as many species of Myrtaceae, and Aquifoliaceae, varying according to geographical location (Coradin et al., 2011; Meyer et al., 2013). This composition was observed in the analyzed caívas.

However, these areas had lower density, diversity, and basal area, comparatively to other remnants protected by Conservation Units. Since there is no historical record of clear-cutting in these areas, the selective cutting of recurrence of tree species, mowing and cattle grazing in the understory and intensification or favoring of the permanence of Ilex paraguariensis in this scenario were determinants (Amaral et al., 2013; Fiorentin et al., 2015).

There was a predominance of individuals that were smaller than expected adult representatives of the different species in the evaluation of stratification and basal area. That is, the species were mostly represented by young individuals. This result can be considered an 


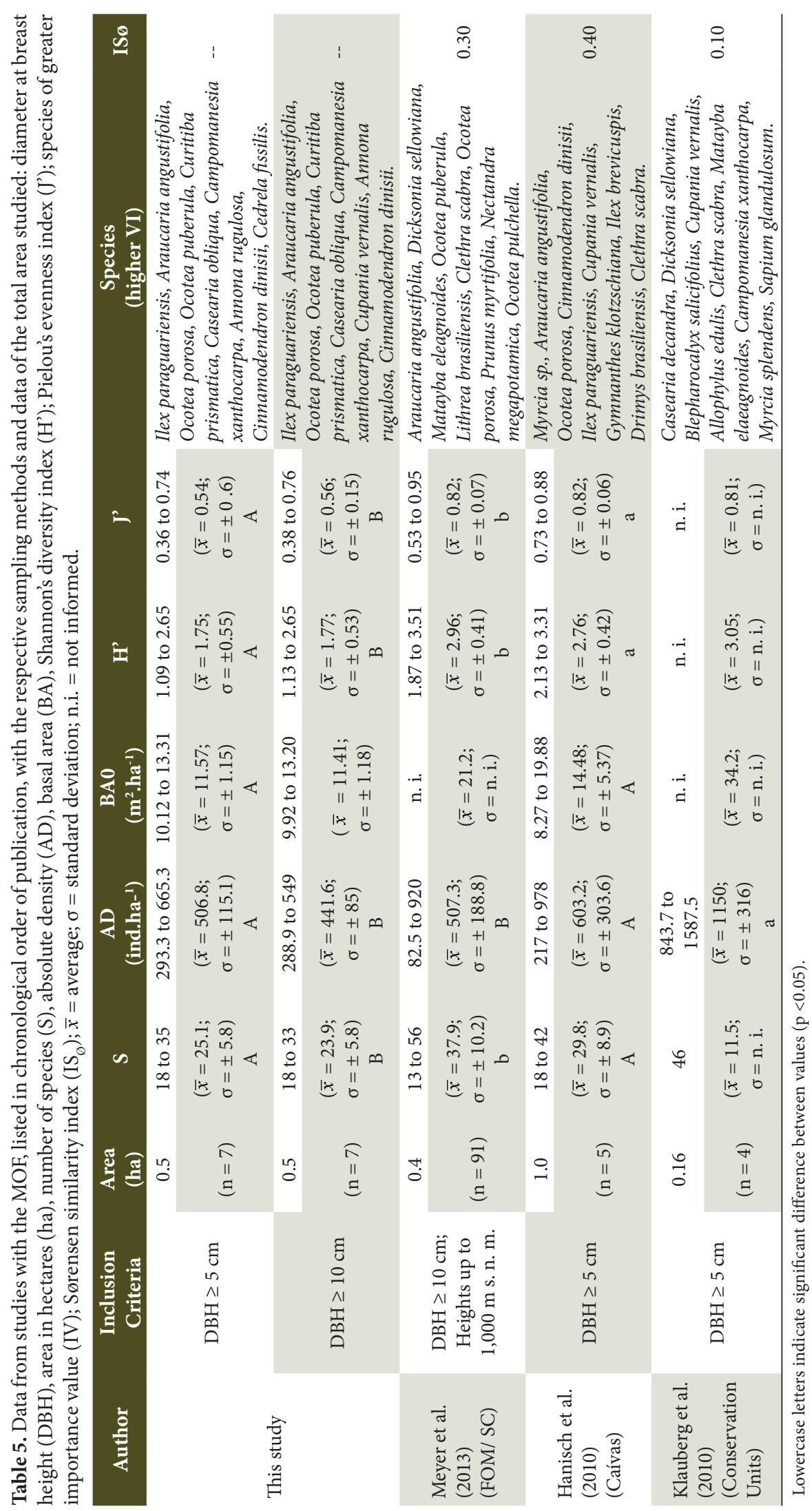


additional indicator of the selective cutting of mature individuals (of a larger size). Also, the predominance of secondary and pioneer species can be considered as indicative of the action of repeated disturbances over the years.

However, the influence of fragmentation and isolation on the studied areas was not evaluated. Habitat fragmentation is a generic term that describes the complete process of disaggregating a large landscape unit into smaller area units, isolated from one another by an array of different habitats. Isolation reduces connectivity between populations, reducing their likelihood of persistence. Additionally, the effects of disruption may restrict the distribution of many organisms to the interior of forest fragments due to changing conditions imposed by the new fragment-environment interface (Murcia, 1995) and the effective conserved area can be consequently smaller than this reserve area (Sampaio \& Scariot, 2011).

However, geographical isolation is not something absolutely quantifiable, which can only be interpreted regarding the permeability of the matrix of the dispersion characteristics of the species concerned and the time scale on which these effects may become apparent (Didham, 2010).

Future detailed studies of the regeneration component as well as the distinct diasporas dispersal vectors activity may provide more consistent data to better identify the conditioning factors of the floristic and structural composition of these caívas.

Also, with the progressive and continuous deforestation in forested areas, given its floristic reliability, the caívas represent important areas of conservation. According to data from Fundação SOS Mata Atlântica (2015), the State of Santa Catarina accounts for 283.168 deforested hectares since 1985 of which 692 hectares were registered in the last technical report, regarding the period between 2013 and 2014. In 2013, a total decrease of 69 ha in forest cover was registered for the municipalities of Canoinhas, Três Barras, Irineópolis and Porto União (Fundação SOS Mata Atlântica, 2014).

In this scenario, the deployment of deforestation containment measures and recovery of caívas are necessary, as conservation and sustainable use of space. Also, dynamic natural environments, the management of caívas should be performed in habitat management context for conservation, as explained in Ausden (2007), that is the inside of properties, reducing the areas of mowing, promoting the enrichment planting of native species and the control of invasive species entrance.

However, considering that they are cultural environments, it is essential to integrate these conservation actions into the current use of these spaces as providers of socioeconomic benefits. According to Hanisch et al. (2016), the traditional handling of caívas has been constantly threatened due to the low revenue generation compared to other more environmentally aggressive alternatives. In this perspective, to identify technological alternatives to improve the pasture in caívas to allow the suitable animal foraging and increase in livestock production, ensuring economic and social sustainability without causing significant impact to the tree component is the biggest challenge.

Also, long-term maintenance of these remnants must be linked to a conservation effort landscape level. Therefore, the competent institutions must act in a coordinated way to reduce the fragmentation and disconnection of the various remnants of the region. The participative establishment of ecological corridors, reforesting interconnection tracks between fragments in private areas and established conservation areas shall promote increased diversity in the biome of the flora and fauna in which caívas are inserted (Quiroga \& Soria, 2014).

\section{CONCLUSIONS}

The caívas have heterogeneous landscapes as expected for remnants of MOF. This type of regional environment presents high floristic integrity, only with density and diversity of species in their composition reduced to unmanaged remnants (Conservation Units). The recurrence of selective cutting of tree species, mowing and grazing of cattle in the understory and cultivation of yerba mate are shown as determining factors in this scenario.

However, future detailed studies of the regeneration component as well as the distinct diaspores dispersal vectors activity may provide more consistent data for a more complete assessment of ecological dynamics environment to better identify the factors that determine the floristic composition and structure of these caívas. 


\section{ACKNOWLEDGEMENTS}

The authors would like to thank the following institutions: Agricultural Research and Rural Extension Company of Santa Catarina (EPAGRI), Experimental Station of Canoinhas-SC, Brazilian Agricultural Research Corporation - Embrapa Forestry Colombo-PR Research Unit, and Chico Mendes Institute for Biodiversity Conservation (ICMBio) - Três Barras National Forest (FLONA Três Barras-SC), for all the logistical and operational support provided during the field activities phases; Academic Publishing Advisory Center (CAPA) of the Federal University of Paraná (UFPR) for the assistance and work with English language translation.

\section{SUBMISSION STATUS}

Received: 29 jul., 2017

Accepted: 20 ago., 2017

\section{CORRESPONDENCE TO}

\section{Lígia Carolina Alcântara Pinotti}

Pós-Graduação em Agronomia, Universidade

Federal do Paraná - UFPR, Rua dos

Funcionários, 1540, Cabral, CEP 80035-050,

Curitiba, PR, Brasil

email:pinotti@ufpr.br

\section{FINANCIAL SUPPORT}

Coordenação de Aperfeiçoamento de Pessoal de Nível Superior (CAPES) and Pró-Reitoria de Pesquisa e Pós-Graduação (PRPPG-UFPR).

\section{REFERENCES}

Amaral LP, Ferreira RA, Lisboa GS, Longhi SJ, Watzlawick LF. Variabilidade espacial do Índice de Diversidade de Shannon-Wiener em FOM. Scientia Forestalis 2013; 41(97): 83-93.

Ausden M. Habitat management for conservation - a handbook of techniques. Oxford: Oxford University Press; 2007.

Bonn LC, Hanisch AL, Marques AC. Melhoramento de caívas no Planalto Norte de Santa Catarina. Revista Agriculturas 2011; 8: 6-11.
Coradin L, Siminski A, Reis A. Espécies nativas da flora brasileira de valor econômico atual ou potencial: plantas para o futuro - Região Sul. Brasília: MMA; 2011.

Didham RK. Ecological consequences of habitat fragmentation. In: eLS, editors. Encyclopedia of Life Sciences. Chichester: John Wiley \& Sons Ltd; 2010. https:// doi.org/10.1002/9780470015902.a0021904.

Fidalgo O, Bononi VLR. Técnicas de coleta, preservação e herborização de material botânico. São Paulo: Instituto de Botânica; 1989.

Fiorentin LD, Téo SJ, Schneider CR, Costa RH, Batista S. Análise florística e padrão espacial da regeneração natural em área de FOM na Região de Caçador, SC. Floresta e Ambiente 2015; 22(1): 60-70.

Flora do Brasil. 2020 em construção [online]. Rio de Janeiro: Jardim Botânico; 2016 [cited 2016 Apr 26]. Available from: http://floradobrasil.jbrj.gov.br/

Fundação SOS Mata Atlântica. Atlas dos remanescentes florestais da Mata Atlântica e ecossistemas associados no período de 2012-2013. São Paulo: INPE; 2014.

Fundação SOS Mata Atlântica. Fundação e INPE divulgam dados do atlas dos remanescentes florestais da Mata Atlântica no período de 2014 a 2015 [online]. São Paulo: Fundação SOS Mata Atlântica; 2015 [cited 2016 May 25]. Available from: https://www.sosma.org.br/projeto/atlas-da-mataatlantica/dados-mais-recentes/

Gasper AL, Sevegnani L, Vibrans AC, Sobral M, Uhlmann A, Lingner DV et al. Inventário florístico florestal de Santa Catarina: espécies da FOM. Rodriguésia 2013; 64(2): 2013.

Hanisch AL, Radomski MI, Bona LC, Marques AC. Melhoria da produção animal em áreas de caíva e sua contribuição para a viabilização de corredores ecológicos. DRd - Desenvolvimento Regional em Debate 2016; 6(2): 170-188.

Hanisch AL, Vogt GA, Marques ADC, Bona LC, Bosse D. Estrutura e composição florística de cinco áreas de caíva no Planalto Norte de Santa Catarina. Pesquisa Florestal Brasileira 2010; 30(64): 303-310.

Instituto Brasileiro de Geografia e Estatística. Manual técnico da vegetação brasileira. 2. ed. Rio de Janeiro: IBGE; 2012.

Klauberg C, Paludo GF, Bortoluzzi RLC, Mantovani A. Florística e estrutura de um fragmento de FOM no Planalto Catarinense. Biotemas 2010; 23(1): 35-47.

Lacerda AEB. Conservation strategies for Araucaria Forests in Southern Brazil: assessing current and alternative approaches. Biotropica 2016; 48(4): 537-544.

Magurran AE. Ecological diversity and its measurement. New Jersey: Princeton University Press; 1988.

Marques AC, Mattos AG, Bona LC, Reis MS. Florestas Nacionais e desenvolvimento de pesquisas: o manejo da erva-mate (Ilex paraguariensis A.St.-Hil.) na Flona de Três Barras/SC. Biodiversidade Brasileira 2012; 2(2): 4-17. 
Mello AJM, Peroni N. Cultural landscapes of the Araucaria Forests in the northern plateau of Santa Catarina, Brazil. Journal of Ethnobiology and Ethnomedicine 2015; 11(51): 1-14.

Meyer L, Sevegnani L, Gasper AL, Schorn LA, Vibrans AC, Lingner DV et al. Fitossociologia do componente arbóreo/ arbustivo da FOM em Santa Catarina. In: Vibrans AC, Sevegnani L, Gasper AL, Lingner DV, editors. Inventário florístico florestal de Santa Catarina. Blumenau: Edifurb; 2013. (FOM; vol. III).

Mueller-Dombois D, Ellenberg H. Aims and methods of vegetation ecology. New York: Wiley; 1974.

Murcia C. Edge effects in fragmented forests: implications for conservation. Trends in Ecology \& Evolution 1995; 10(2): 58-62. PMid:21236953.

Quiroga FG, Soria JA. Los corredores ecológicos y su importancia ambiental: Propuestas de actuación para fomentar la permeabilidad y conectividad aplicadas al entorno del río Cardeña (Ávila y Segovia). Observatorio Medioambiental 2014; 17: 253-298.

Reis MS, Silva CV, Mattos AG, Zechini AA, Mantovani A, Peroni N. Caívas and their contribution to the conservation of Atlantic forest landscapes in Brazil. In: Boef WS, Subedi A, Peroni N, Thijssen M, O'Keeffe E, editors. Community biodiversity management: promoting resilience and the conservation of plant genetic resources. London: Routledge; 2013.

Sampaio AB, Scariot A. Efeito de borda na diversidade, composição e estrutura da comunidade arbórea em uma floresta estacional decidual no Brasil Central. Revista Árvore 2011; 35(5): 1121-1134.

Souza AF, Cortez LSR, Longhi SJ. Native forest management in subtropical South America: long-term effects of logging and multiple-use on forest structure and diversity. Biodiversity and Conservation 2012; 21(8): 1953-1969.

Vibrans AC, Sevegnani L, Gasper AL, Lingner DV. Inventário florístico florestal de Santa Catarina. Blumenau: Edifurb; 2013. (FOM; vol. III).

Vibrans AC, Sevegnani L, Uhlmann A, Schorn LA, Sobral MG, De Gasper AL et al. Structure of mixed ombrophyllous forests with Araucaria angustifolia (Araucariaceae) under external stress in Southern Brazil. Revista de Biología Tropical 2011; 59(3): 1371-1387. PMid:22017139.

Zamorano-Elgueta C, Cayuela L, Rey-Benayas JM, Donoso PJ, Geneletti D, Hobbs RJ. The differential influences of human-induced disturbances on tree regeneration community: a landscape approach. Ecosphere 2014; 5(7): 1-17. 


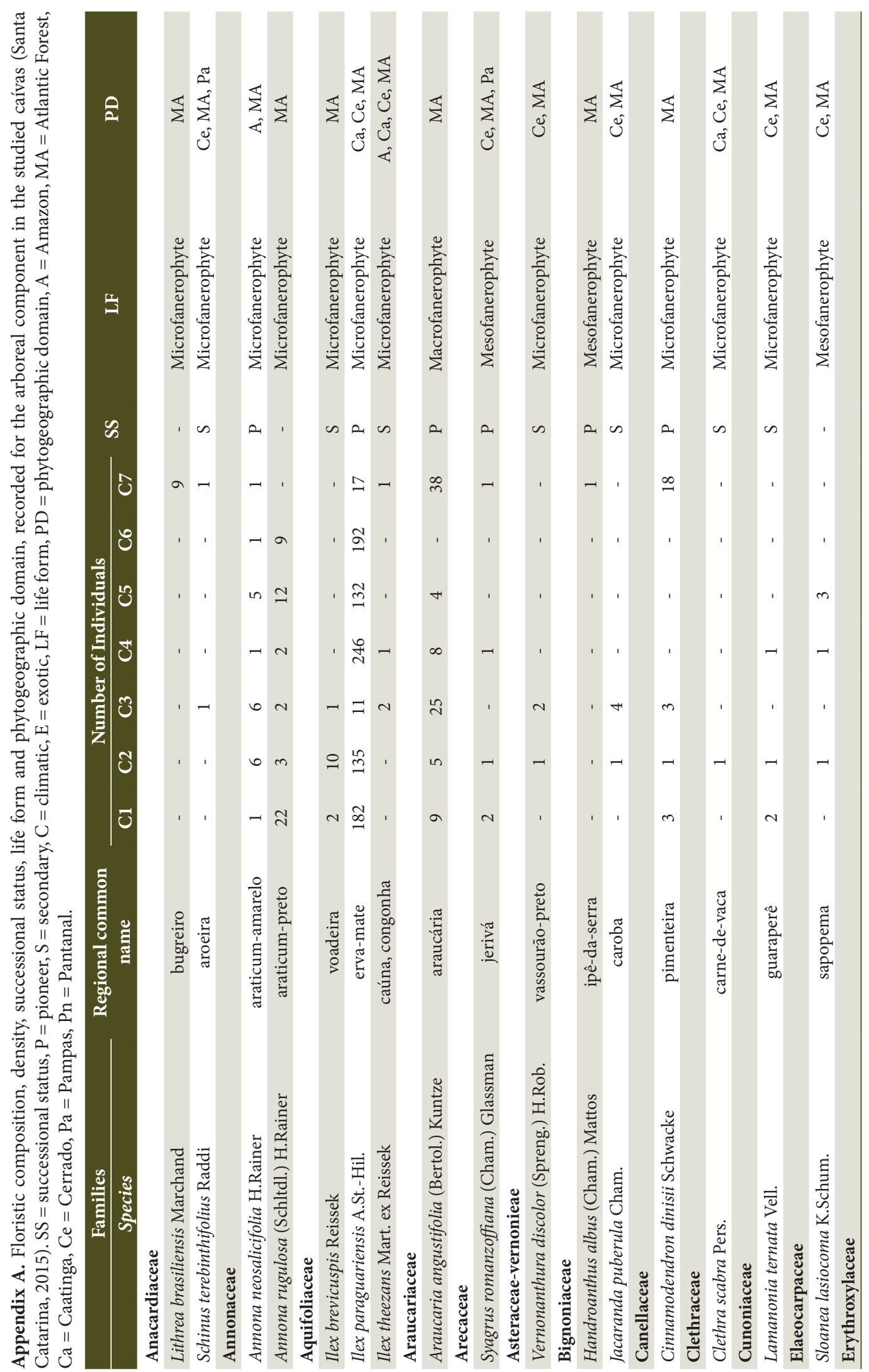




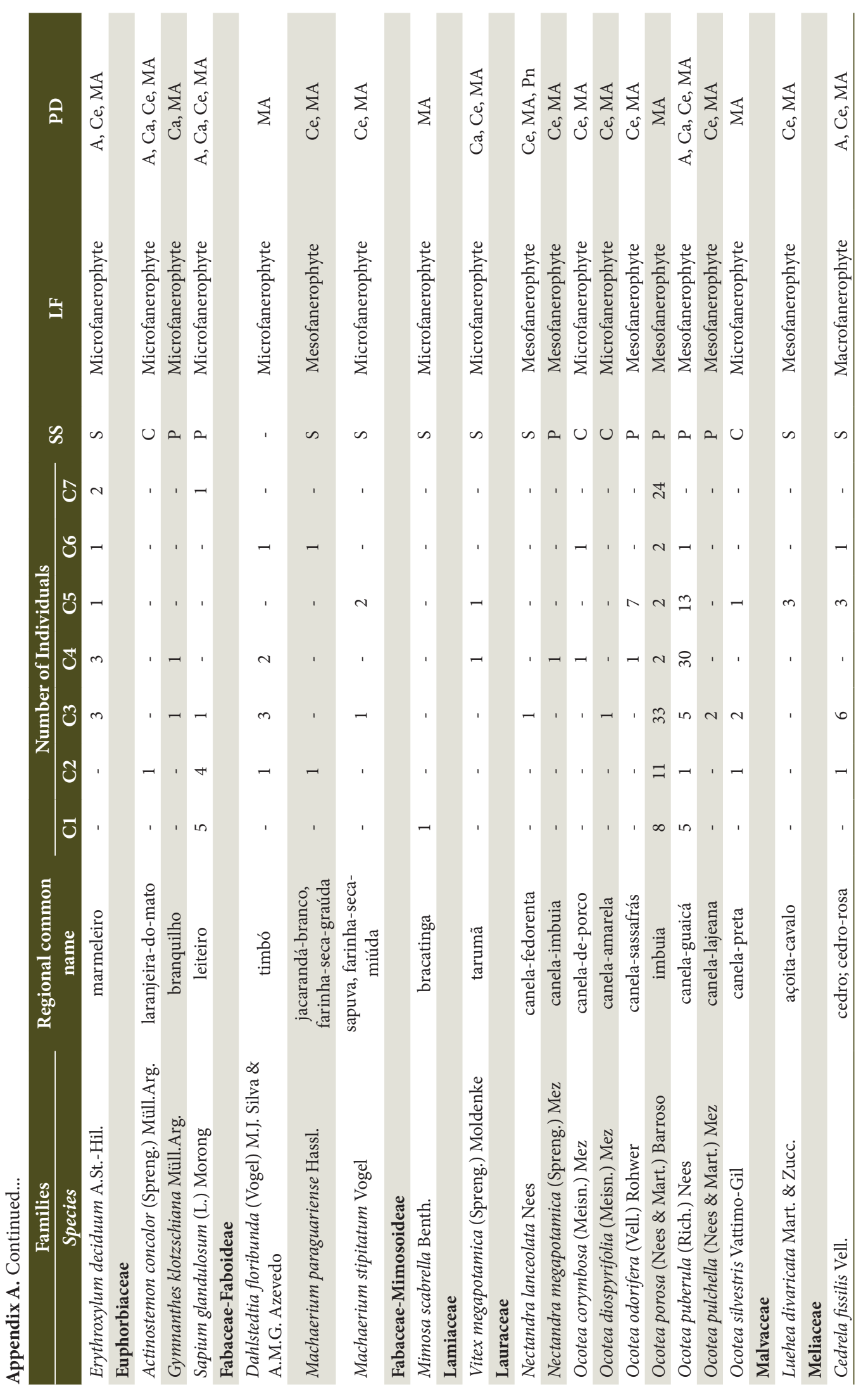




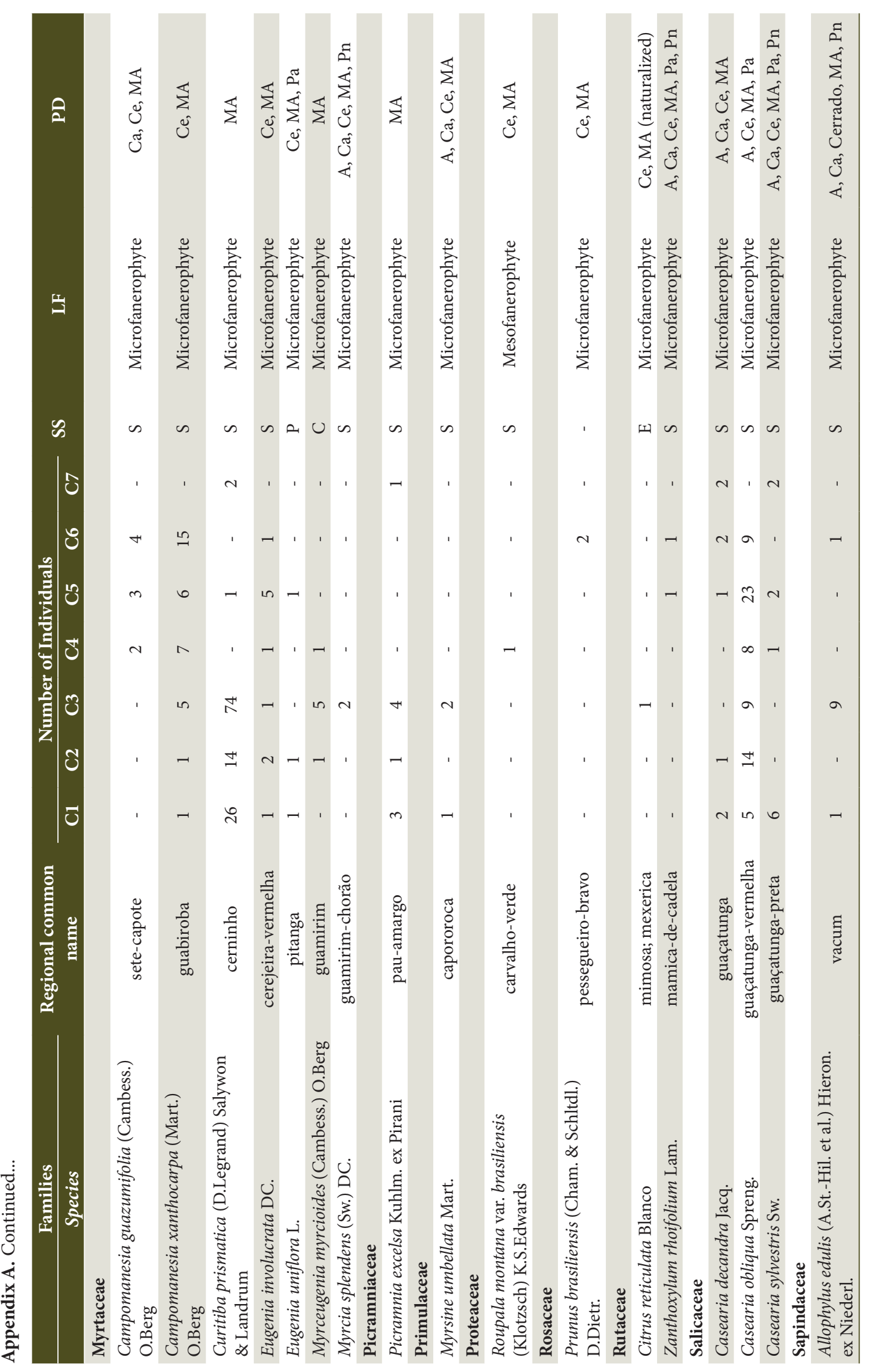




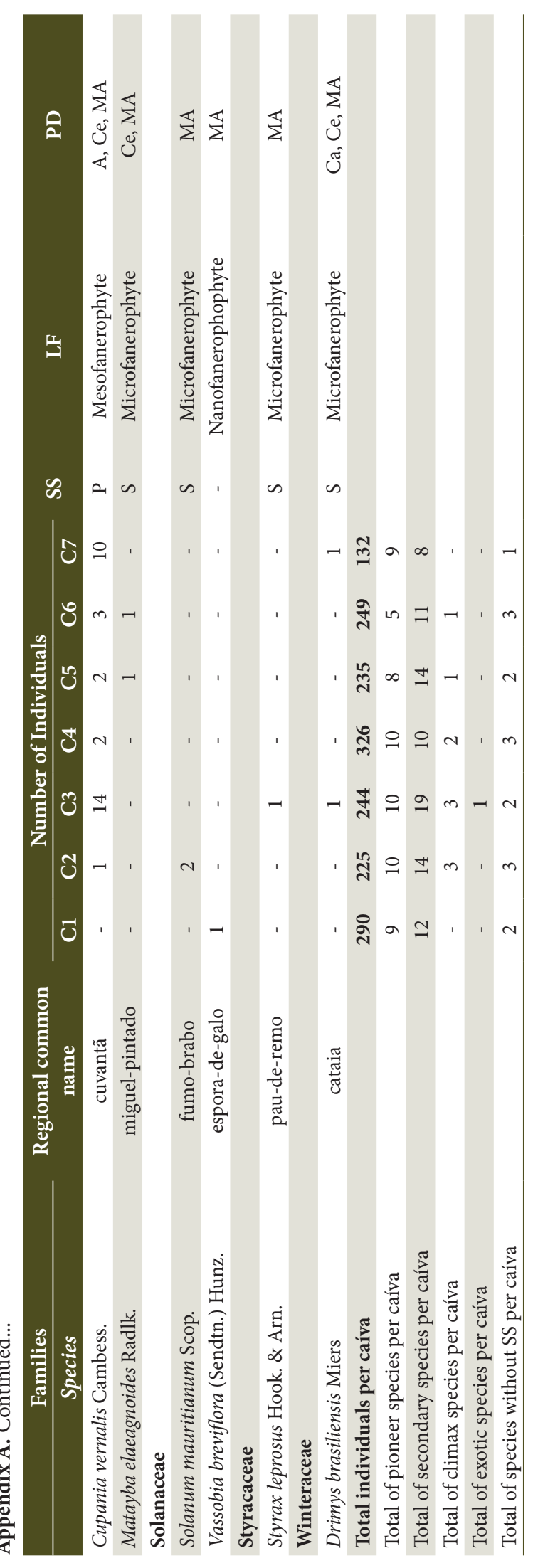

